\title{
Article \\ Comprehensive Evidence of Carrier-Mediated Distribution of Amantadine to the Retina across the Blood-Retinal Barrier in Rats
}

\author{
Yusuke Shinozaki, Shin-ichi Akanuma $\mathbb{1}$, Yuika Mori, Yoshiyuki Kubo and Ken-ichi Hosoya *(D) \\ Department of Pharmaceutics, Graduate School of Medicine and Pharmaceutical Sciences, University of Toyama, \\ 2630 Sugitani, Toyama 930-0194, Japan; m2061220@ems.u-toyama.ac.jp (Y.S.); \\ akanumas@pha.u-toyama.ac.jp (S.-i.A.); s1860308@ems.u-toyama.ac.jp (Y.M.); \\ kubo.yoshiyuki.jf@teikyo-u.ac.jp (Y.K.) \\ * Correspondence: hosoyak@pha.u-toyama.ac.jp; Tel.: +81-76-434-7505
}

Citation: Shinozaki, Y.; Akanuma, S.-i.; Mori, Y.; Kubo, Y.; Hosoya, K.-i. Comprehensive Evidence of

Carrier-Mediated Distribution of Amantadine to the Retina across the Blood-Retinal Barrier in Rats. Pharmaceutics 2021, 13, 1339. https:// doi.org/10.3390/pharmaceutics13091339

Academic Editor: Gert Fricker

Received: 12 July 2021

Accepted: 24 August 2021

Published: 26 August 2021

Publisher's Note: MDPI stays neutral with regard to jurisdictional claims in published maps and institutional affiliations.

Copyright: (c) 2021 by the authors. Licensee MDPI, Basel, Switzerland. This article is an open access article distributed under the terms and conditions of the Creative Commons Attribution (CC BY) license (https:// creativecommons.org/licenses/by/ $4.0 /)$.

\begin{abstract}
Amantadine, a drug used for the blockage of NMDA receptors, is well-known to exhibit neuroprotective effects. Accordingly, assessment of amantadine transport at retinal barriers could result in the application of amantadine for retinal diseases such as glaucoma. The objective of this study was to elucidate the retinal distribution of amantadine across the inner and outer blood-retinal barrier (BRB). In vivo blood-to-retina $\left[{ }^{3} \mathrm{H}\right]$ amantadine transport was investigated by using the rat retinal uptake index method, which was significantly reduced by unlabeled amantadine. This result indicated the involvement of carrier-mediated processes in the retinal distribution of amantadine. In addition, in vitro model cells of the inner and outer BRB (TR-iBRB2 and RPE-J cells) exhibited saturable kinetics ( $K_{\mathrm{m}}$ in TR-iBRB2 cells, $79.4 \mu \mathrm{M} ; K_{\mathrm{m}}$ in RPE-J cells, 90.5 and $9830 \mu \mathrm{M}$ ). The inhibition of $\left[{ }^{3} \mathrm{H}\right]$ amantadine uptake by cationic drugs/compounds indicated a minor contribution of transport systems that accept cationic drugs (e.g., verapamil), as well as solute carrier (SLC) organic cation transporters. Collectively, these outcomes suggest that carrier-mediated transport systems, which differ from reported transporters and mechanisms, play a crucial role in the retinal distribution of amantadine across the inner/outer BRB.
\end{abstract}

Keywords: amantadine; blood-retinal barrier; drug delivery; retinal disease; NMDA receptor; inner $\mathrm{BRB}$; retinal capitally endothelial cells; outer BRB; retinal pigment epithelial cells; transporter

\section{Introduction}

Retinal neurogenerative diseases, such as glaucoma and diabetic retinopathy, cause progressive visual deficit $[1,2]$. It is well-known that the progression of the visual deficit involves $\mathrm{N}$-methyl-D-aspartate (NMDA) receptors [3,4]. Previous in vitro and in vivo analyses have indicated the involvement of overactivation of NMDA receptors in the loss of retinal ganglion cells (RGCs) [5,6], which transmit light stimuli from the eye to the brain. Recently, there has been an attempt to block NMDA receptors for the treatment of retinal diseases. For example, it has been reported that memantine, which is an adamantane derivative and an inhibitor of NMDA receptors, has been shown to exhibit neuroprotection in the retina of animal models of retinal diseases, both in vitro and in vivo [7,8]. Moreover, pharmacotherapy with memantine for glaucoma has reached phase III clinical trials [9]. Although a clinical trial of memantine failed [10], it is believed that adamantane derivatives have the potential to treat retinal diseases. Among the adamantane derivatives that are utilized for the blockage of NMDA receptors in clinical practice, amantadine shows the simplest structure. Therefore, scrutiny of the manner of retinal amantadine distribution could contribute to the clinical application of these derivatives.

The blood-retinal barrier (BRB) is known to regulate retinal drug distribution and is composed of retinal capillary endothelial and pigmented epithelial cells, termed the inner 
BRB and outer BRB, respectively [11]. Although the paracellular transport of compounds across these barriers is restricted by cellular tight junctions, recent studies have suggested that several ionic nutrients and drugs are supplied by blood-to-retina transport mediated by various plasma membrane transporters and transport systems [12]. As the pKa value of amantadine is 10.1, it is indicated that amantadine exists in the cationic form under physiological conditions ( $\mathrm{pH} ~ 7.4$ ) [13]. Accordingly, to develop a suitable strategy for efficient retinal amantadine distribution, an understanding of the retinal distribution of amantadine across the BRB would be valuable, in addition to clarifying the involvement of plasma membrane transport systems during this process.

To date, several solute carrier (SLC) transporters have been identified in amantadine transport in vivo and in vitro. As shown in Table 1, the roles of multidrug and toxin extrusion protein 1 (MATE1/Slc47a1) and neutral and basic amino acid transporter (ATB ${ }^{0,+} /$ Slc6a14) at several tissues in amantadine transport have been reported [14,15]. Moreover, amantadine is reportedly a substrate for SLC organic cation transporter 1, abbreviated as OCT1 (Slc22a1), and OCT2 (Slc22a2) [16,17]. Among these transporters, mRNA expression of MATE1 has been observed in the inner and outer BRB model cells $[18,19]$. In addition to MATE1, the expression of other organic cation transporter subtypes has been documented. For example, plasma membrane monoamine transporter (PMAT/slc29a4) and organic cation/L-carnitine transporters 1-2 (OCTN1-2/slc22a4-5) are expressed at the BRB $[18,19]$. Moreover, putative cationic drug transport systems that accept several cationic and lipophilic drugs, including verapamil, clonidine, and propranolol, are known to exist in the inner BRB [20-23]. In these previous reports, amantadine reportedly exhibited an inhibitory effect on the uptake of these cationic drugs in inner BRB model cells, namely TR-iBRB2 cells [24]. Based on these lines of evidence, it can be speculated that these transporters and putative transport systems at the inner and outer BRB participate in amantadine transport to the retina across the BRB.

The present study aimed to clarify the details underlying the retinal distribution of amantadine. Herein, we used the retinal uptake index (RUI) experiment to elucidate the role of carrier-mediated processes in the retinal transfer of amantadine. In addition, the properties of amantadine transport across the inner and outer BRB were determined by using TR-iBRB2 cells and a conditionally immortalized rat RPE cell line (RPE-J cells) [25].

Table 1. Candidates of amantadine transporter and transport system in the retina.

\begin{tabular}{|c|c|c|c|}
\hline \multicolumn{2}{|c|}{ Name } & \multirow{2}{*}{$\begin{array}{c}\text { Is Amantadine Accepted } \\
\text { as a Substrate? } \\
\text { Yes [15] }\end{array}$} & \multirow{2}{*}{$\begin{array}{c}\text { Is It Expressed } \\
\text { in the Retina? } \\
\text { N.D. }\end{array}$} \\
\hline Slc6a14 & $\mathrm{ATB}^{0,+}$ & & \\
\hline Slc22a1 & OCT1 & Yes [16] & N.D. \\
\hline Slc22a2 & OCT2 & Yes [17] & N.D. \\
\hline Slc22a3 & OCT3 & N.D. & N.D. \\
\hline Slc22a4 & OCTN1 & N.D. & Yes (mRNA) [18] \\
\hline Slc22a5 & OCTN2 & N.D. & Yes (mRNA) [18] \\
\hline Slc29a4 & PMAT & N.D. & Yes (mRNA) [19] \\
\hline Slc47a1 & MATE1 & Yes [14] & Yes (mRNA) [19] \\
\hline $\begin{array}{l}\text { Putative transport } \\
\text { systems }\end{array}$ & $\begin{array}{l}\text { Verapamil } \\
\text { Clonidine } \\
\text { Propranolol }\end{array}$ & N.D. & Yes [20-23] \\
\hline
\end{tabular}

N.D., not determined.

\section{Materials and Methods}

\subsection{Animals and Reagents}

The animal experiments performed in this study were approved by the Animal Care Committee of the University of Toyama with the registration numbers of A2017PHA-6 and A2020PHA-1. Male Wistar/ST rats (approximately 200 g; Japan SLC, Hamamatsu, Japan) were maintained under controlled conditions (12/12 h dark/light cycle; temperature, $\sim 23^{\circ} \mathrm{C}$; humidity, around $50 \%$ ). Male rats present an advantage for the comparison of 
previous reports of in vivo retinal distribution, as quantitative data of compound distribution to the retina have been obtained by using male rats [26]. A total of 13 rats were used for the assessment of in vivo blood-to-retina transport (control, $n=5$; co-administration of unlabeled amantadine, $n=4$; co-administration of $\mathrm{PAH}, n=4)$. Amantadine $\mathrm{HCl}$, $\left[{ }^{3} \mathrm{H}\right]-\left(\left[{ }^{3} \mathrm{H}\right]\right.$ amantadine; $\left.0.3 \mathrm{Ci} / \mathrm{mmol}\right)$ was obtained from Moravek (Brea, CA, USA). From American Radiolabeled Chemicals (St. Louis, MO, USA), $n-\left[1-{ }^{14} \mathrm{C}\right]$ butanol $\left(\left[{ }^{14} \mathrm{C}\right] n\right.$ butanol; $\left.2.0 \times 10^{3} \mu \mathrm{Ci} / \mathrm{mmol}\right)$ and verapamil $\left[\mathrm{N}\right.$-methyl $\left.-{ }^{3} \mathrm{H}\right]$ hydrochloride $\left(\left[{ }^{3} \mathrm{H}\right]\right.$ verapamil; $80 \mathrm{Ci} / \mathrm{mmol}$ ) were purchased. Unlabeled drugs and compounds used in this study were commercially available.

\subsection{Assessment of In Vivo Blood-to-Retina Transport}

Rats were anesthetized by an intraperitoneal injection of pentobarbital sodium at $50 \mathrm{mg} / \mathrm{kg}$. Using the rats, intracarotid artery injection was performed by following the method given in previous manuscripts [20-22,26], and the details of the procedure are given in the Supplementary Materials. The functional retinal compound distribution as a percentage of the in vivo retinal transfer of $\left[{ }^{14} \mathrm{C}\right] n$-butanol (RUI) was determined by using Equation (1).

RUI $(\%)=\left(\left[{ }^{3} \mathrm{H}\right]\right.$ amantadine $/\left[{ }^{14} \mathrm{C}\right] n$-butanol (in retina) $) /\left(\left[{ }^{3} \mathrm{H}\right]\right.$ amantadine $/\left[{ }^{14} \mathrm{C}\right] n$-butanol (in the injected solution) $) \times 100$

\subsection{In Vitro Transport Study}

In 10\% fetal bovine serum (FBS; Merck, Darmstadt, Germany)-containing Dulbecco's modified Eagle's medium (DMEM; Nissui Pharmaceutical, Tokyo, Japan) with $20 \mathrm{mM} \mathrm{NaHCO} 3,0.19 \mathrm{mM}$ benzylpenicillin potassium, and $0.14 \mathrm{mM}$ streptomycin sulfate, TR-iBRB2 cells (passage number $32-60)$ were cultured according to previous reports [20-22,24]. As described previously [25,27], RPE-J cells (passage number 79-92) were cultured in DMEM with $4 \% \mathrm{FBS}, 20 \mathrm{mM} \mathrm{NaHCO}_{3}$, and $0.1 \mathrm{mM}$ non-essential amino acid (FUJIFILM Wako Pure Chemical, Osaka, Japan) containing $0.16 \mathrm{mM}$ benzylpenicillin potassium and $0.17 \mathrm{mM}$ streptomycin sulfate. In accordance with established protocols for the uptake study [20-22], the cells were seeded at a density of $1.0 \times 10^{5}$ cells/well onto a collagen I-coated 24-well plate (BioCoat ${ }^{\mathrm{TM}}$ Collagen I Cellware, Corning, Corning, NY, USA) and cultured for 2 days, at $33{ }^{\circ} \mathrm{C}$, under $5 \% \mathrm{CO}_{2}$ / air. Referring to the previous reports [20-23,28,29], we started the uptake reaction, and the details of the procedure are included in the Supplemental Materials.

The uptake activities for $\left[{ }^{3} \mathrm{H}\right] \mathrm{amantadine}$ and $\left[{ }^{3} \mathrm{H}\right]$ verapamil were calculated as the cell/medium ratio, using Equation (2).

Cell $/$ medium ratio $=\left[{ }^{3} \mathrm{H}\right]$ compound $(\mathrm{dpm})$ per cell protein $(\mathrm{mg}) /\left[{ }^{3} \mathrm{H}\right]$ compound $(\mathrm{dpm})$ per medium $(\mu \mathrm{L})$

Kinetic parameters for cell uptake, such as the maximal uptake rate $\left(V_{\max }\right)$, Michaelis-Menten constant $\left(K_{\mathrm{m}}\right)$, and non-saturable uptake clearance $\left(K_{\mathrm{d}}\right)$, were obtained by using the nonlinear leastsquares regression analysis program (MULTI) [30] with Equations (3)-(5), where the uptake rate of the test compound and its concentration were $V$ and $S$, respectively.

$$
\begin{gathered}
V=\left(V_{\max } \times S\right) /\left(K_{\mathrm{m}}+S\right) \\
V=\left(V_{\max } \times S\right) /\left(K_{\mathrm{m}}+S\right)+K_{\mathrm{d}} \times S \\
V=\left(V_{\max 1} \times S\right) /\left(K_{\mathrm{m} 1}+S\right)+\left(V_{\max 2} \times S\right) /\left(K_{\mathrm{m} 2}+S\right)
\end{gathered}
$$

\subsection{Data and Statistical Analyses}

All the data are shown as the mean \pm standard deviation (SD). Using the unpaired two-tailed Student's $t$-test (two groups) or one-way analysis of variance followed by Dunnett's test (more than two groups), statistical differences were evaluated.

\section{Results}

\subsection{In Vivo Blood-to-Retina Transport of $\left[{ }^{3} H\right]$ Amantadine across the BRB}

The in vivo RUI was observed to be $129 \pm 13 \%$ (Figure 1), indicating that retinal distribution of $\left[{ }^{3} \mathrm{H}\right]$ amantadine is 1.29 -fold greater than that of $\left[{ }^{14} \mathrm{C}\right] n$-butanol. Following co-administration of $50 \mathrm{mM}$ unlabeled amantadine, the RUI value significantly decreased by $44 \%$. To test the effect of compounds at the same concentration, co-administration of $50 \mathrm{mM}$-aminohippuric acid (PAH), 
which is an anionic compound that is reported to have no effect on the retinal distribution of cationic drugs, such as propranolol and clonidine [21,22], was performed. As a result, no significant effect was observed in the presence of $50 \mathrm{mM}$ PAH (Figure 1).

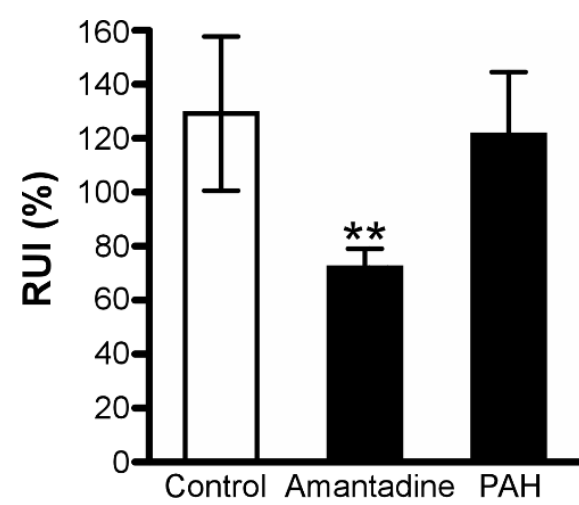

Figure 1. $\left[{ }^{3} \mathrm{H}\right]$ Amantadine RUI in rats. $\left[{ }^{3} \mathrm{H}\right]$ Amantadine $(5 \mu \mathrm{Ci} / \mathrm{rat})$ and $\left[{ }^{14} \mathrm{C}\right] n$-butanol $(0.5 \mu \mathrm{Ci} / \mathrm{rat})$ were injected in the absence (control, $n=5)$ or presence of $50 \mathrm{mM}$ unlabeled amantadine $(n=4)$ or $50 \mathrm{mM}$ PAH $(n=4)$. Each column, expressing $\left[{ }^{3} \mathrm{H}\right]$ amantadine RUI, represents the mean $\pm \mathrm{SD}$; ** $p<0.01$, significant difference from control. RUI, retinal uptake index; $\mathrm{PAH}, p$-aminohippuric acid.

\subsection{Amantadine Uptake Properties in TR-iBRB2 Cells}

TR-iBRB2 cells showed a time-dependent increase in $\left[{ }^{3} \mathrm{H}\right]$ amantadine uptake for at least $5 \mathrm{~min}$ The initial uptake rate was presented as $14.0 \pm 4.1 \mu \mathrm{L} /(\mathrm{min} \cdot \mathrm{mg}$ protein) (Figure $2 \mathrm{~A})$. At $4{ }^{\circ} \mathrm{C}$, the $\left[{ }^{3} \mathrm{H}\right]$ amantadine uptake significantly reduced by $86 \%$ (Figure $2 \mathrm{~A}$ ). Concentration-dependent uptake of amantadine by TR-iBRB2 cells exhibited saturable and non-saturable processes, with a $V_{\max }$ of $1.36 \pm 0.38 \mathrm{nmol} /\left(\mathrm{min} \cdot \mathrm{mg}\right.$ protein), a $K_{\mathrm{m}}$ of $79.4 \pm 27.3 \mu \mathrm{M}$, and a $K_{\mathrm{d}}$ of $2.75 \pm 0.58 \mu \mathrm{L} /(\mathrm{min} \cdot \mathrm{mg}$ protein) (Figure 2B).

A

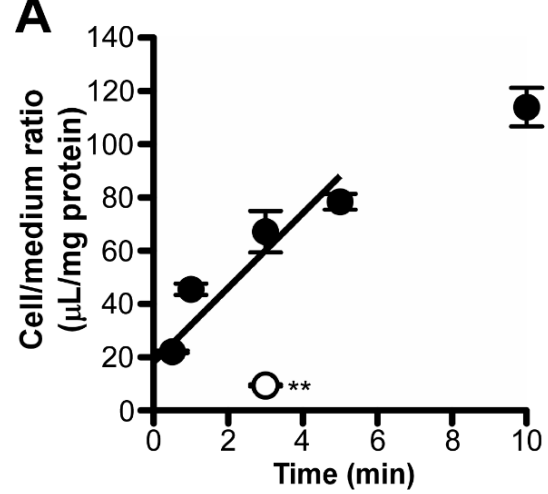

B

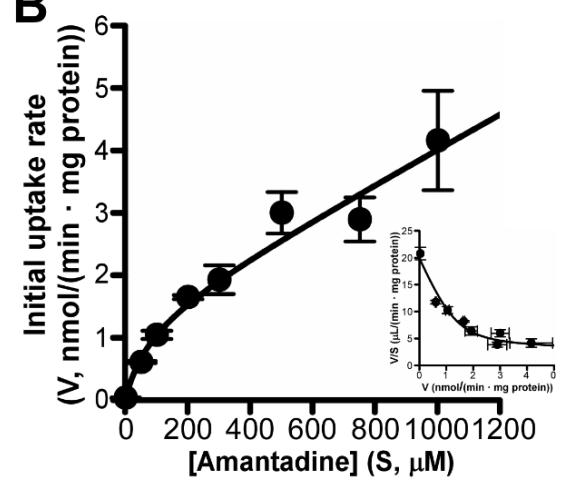

Figure 2. Time-, temperature-, and concentration-dependent uptake of $\left[{ }^{3} \mathrm{H}\right]$ amantadine by TR-iBRB2 cells. (A) Time dependency of $\left[{ }^{3} \mathrm{H}\right]$ amantadine uptake $(1.67 \mu \mathrm{M}, 0.1 \mu \mathrm{Ci} /$ well $)$ by $\mathrm{TR}-\mathrm{iBRB} 2$ cells at $37^{\circ} \mathrm{C}$ (control; closed circles) and effect of low temperature $\left(4^{\circ} \mathrm{C}\right.$; open circle) on the uptake; ${ }^{* *} p<0.01$, significant difference from the control. (B) Concentration dependency of amantadine uptake by TR-iBRB2 cells. Amantadine uptake was examined at $37^{\circ} \mathrm{C}$ for $3 \mathrm{~min}$ over the concentration range of 1.67 to $1000 \mu \mathrm{M}$ and analyzed by using Michaelis-Menten and Eadie-Scatchard (inset) plots. Each point in the figure represents the mean $\pm \operatorname{SD}(n=3)$.

Furthermore, $\mathrm{Na}^{+}$-free and $\mathrm{K}^{+}$-replacement buffer had no significant effect on the uptake of $\left[{ }^{3} \mathrm{H}\right]$ amantadine by TR-iBRB2 cells; however, $\mathrm{Cl}^{-}$-free buffer significantly reduced the uptake of $\left[{ }^{3} \mathrm{H}\right]$ amantadine by $38 \%$ (Figure $3 \mathrm{~A}$ ). At an extracellular $\mathrm{pH}$ of $6.4,\left[{ }^{3} \mathrm{H}\right]$ amantadine uptake by TR-iBRB2 cells was significantly reduced by $64 \%$ (Figure 3B). At an extracellular $\mathrm{pH}$ of 8.4 , we noted the tendency of an increase in uptake of $\left[{ }^{3} \mathrm{H}\right]$ amantadine by TR-iBRB2 cells (Figure $3 \mathrm{~B}$ ). A proton ionophore, namely carbonyl cyanide- $p$-trifluoromethoxyphenylhydrazone (FCCP) [21,27], significantly decreased uptake by $50 \%$ at $50 \mu \mathrm{M}$ (Figure 3C). In previous studies, it was indicated 
the acute treatment and pretreatment of $\mathrm{NH}_{4} \mathrm{Cl}$ caused alkalized and acidified intracellular $\mathrm{pH}$ in endothelial and epithelial cells, respectively $[28,29]$. Although acute $\mathrm{NH}_{4} \mathrm{Cl}$ treatment also induces the neutralization between the acid endosomal/lysosomal and intracellular compartments [27], we performed a study of $\left[{ }^{3} \mathrm{H}\right]$ amantadine uptake with acute and pretreatment of $\mathrm{NH}_{4} \mathrm{Cl}$ to examine the effect of $\mathrm{H}^{+}$-gradient on the intra- and extra-cellular compartments. The uptake was significantly decreased by $80 \%$ and increased by $90 \%$ at alkalized and acidified intercellular $\mathrm{pH}$, respectively (Figure 3D). Under the experimental conditions in Figure 3, there is a possibility that the cytotoxicity may have affected the results of this uptake, because these experimental conditions are not ideal for the culture of these cells. However, the cellular protein amount after the uptake reaction was not significantly altered in each group compared with the control (Supplementary Materials Figure S1). Therefore, the cytotoxic effect caused by these experimental conditions is considered to be minimal.

A

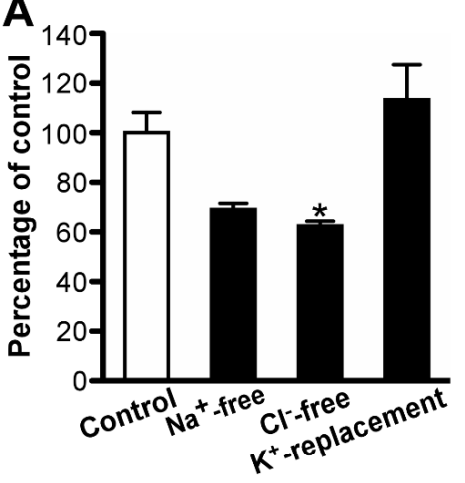

C

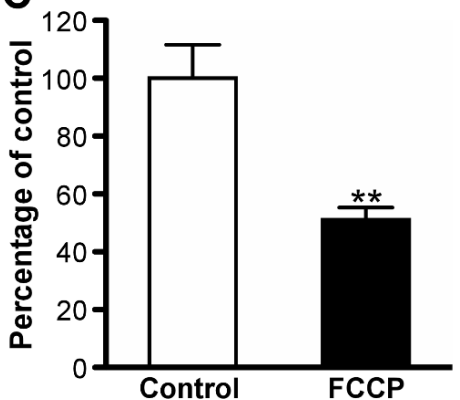

B

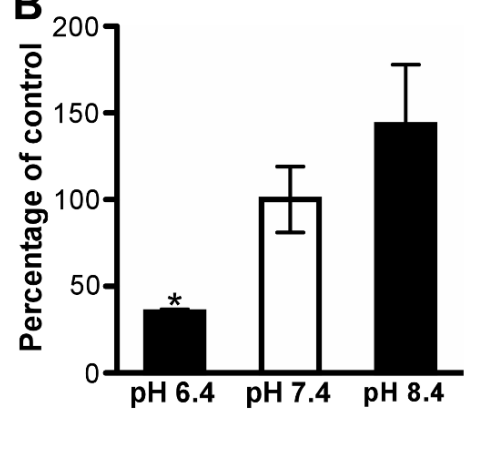

D

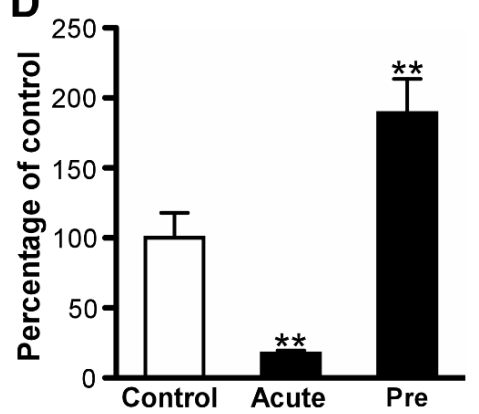

Figure 3. Uptake properties of $\left[{ }^{3} \mathrm{H}\right]$ amantadine by TR-iBRB2 cells. (A) Effect of $\mathrm{Na}^{+}, \mathrm{Cl}^{-}$, and membrane potential on $\left[{ }^{3} \mathrm{H}\right]$ amantadine uptake $\left(1.67 \mu \mathrm{M}, 0.1 \mu \mathrm{Ci} /\right.$ well) for $3 \mathrm{~min}$ at $37^{\circ} \mathrm{C}$. (B) Effect of extracellular $\mathrm{pH}$ on $\left[{ }^{3} \mathrm{H}\right]$ amantadine uptake by TR-iBRB2 cells. (C) Effect of carbonyl cyanide $-p$-trifluoromethoxyphenylhydrazone (FCCP) treatment at $50 \mu \mathrm{M}$ on $\left[{ }^{3} \mathrm{H}\right]$ amantadine uptake. (D) Effect of intracellular $\mathrm{pH}$ on the uptake of $\left[{ }^{3} \mathrm{H}\right]$ amantadine for $15 \mathrm{~s}$ by TR-iBRB2 cells at $37^{\circ} \mathrm{C}$. Pretreatment (Pre) and acute treatment with $30 \mathrm{mM} \mathrm{NH}_{4} \mathrm{Cl}$ were performed to decrease and increase intracellular $\mathrm{pH}$, respectively. Each column in the figure represents the mean $\pm \mathrm{SD}(n=3)$; ${ }^{*} p<0.05,{ }^{* *} p<0.01$, significantly different from the control.

\subsection{Amantadine Uptake Properties in RPE-J Cells}

In the current study, $\left[{ }^{3} \mathrm{H}\right]$ amantadine was time-dependently incorporated for at least $3 \mathrm{~min}$ in RPE-J cells, at an initial uptake rate of $15.9 \pm 0.3 \mu \mathrm{L} /(\mathrm{min} \cdot \mathrm{mg}$ protein) (Figure $4 \mathrm{~A})$. At $4{ }^{\circ} \mathrm{C}$, this uptake was significantly reduced by $87 \%$ (Figure $4 \mathrm{~A}$ ). Amantadine uptake by RPE-J cells involved both high- and low-affinity saturable processes (Figure $4 \mathrm{~B}$ ). Following the calculation, $K_{\mathrm{m} 1}$ and $V_{\max 1}$ values were $90.5 \pm 49.6 \mu \mathrm{M}$ and $0.914 \pm 0.510 \mathrm{nmol} /(\mathrm{min} \cdot \mathrm{mg}$ protein), respectively, for the high-affinity uptake process. For the low-affinity uptake process, the $K_{\mathrm{m} 2}$ and $V_{\max 2}$ values were $9830 \pm 1620 \mu \mathrm{M}$ and $85.3 \pm 11.4 \mathrm{nmol} /(\mathrm{min} \cdot \mathrm{mg}$ protein $)$, respectively.

$\mathrm{Na}^{+}$-free, $\mathrm{Cl}^{-}$-free, and $\mathrm{K}^{+}$-replacement buffers had no significant impact on the uptake of $\left[{ }^{3} \mathrm{H}\right]$ amantadine by RPE-J cells (Figure $5 \mathrm{~A}$ ). The uptake of $\left[{ }^{3} \mathrm{H}\right]$ amantadine by RPE-J cells was significantly decreased by $32 \%$ and increased by $25 \%$ at extracellular $\mathrm{pH}$ of 6.4 and 8.4, respectively (Figure 5B). Furthermore, the uptake of $\left[{ }^{3} \mathrm{H}\right]$ amantadine by RPE-J cells was significantly decreased by $78 \%$ and increased by $18 \%$ at alkalized and acidified intercellular $\mathrm{pH}$, respectively (Figure $5 \mathrm{C}$ ). The 
cellular protein in each group of Figure 5 also had no significant difference compared with control (Supplementary Materials Figure S2).

A

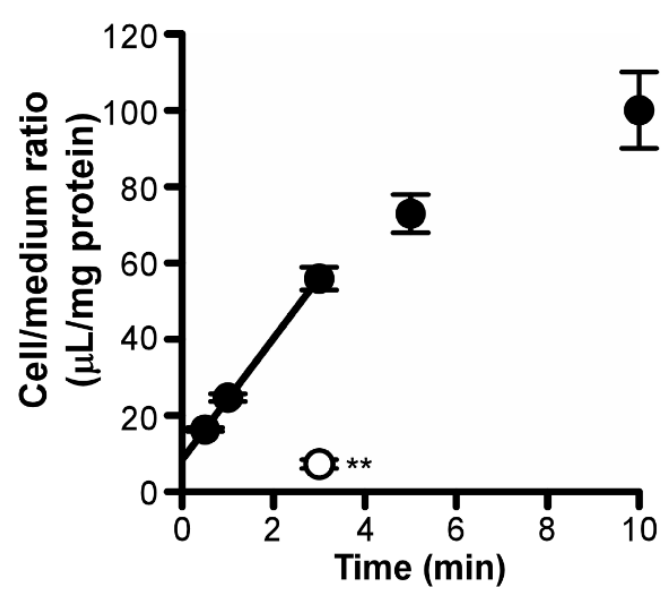

B

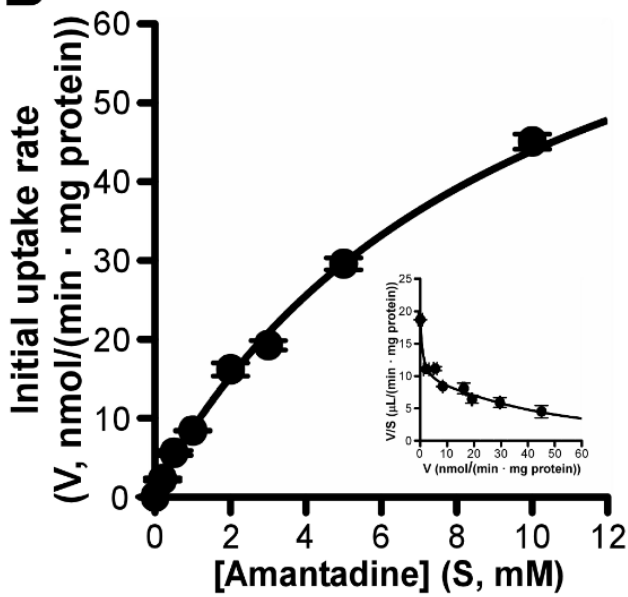

Figure 4. Time-, temperature-, and concentration-dependent uptake of $\left[{ }^{3} \mathrm{H}\right]$ amantadine by RPE-J cells. (A) Time dependency of $\left[{ }^{3} \mathrm{H}\right]$ amantadine uptake $\left(1.67 \mu \mathrm{M}, 0.1 \mu \mathrm{Ci} /\right.$ well) by RPE-J cells $\left(37^{\circ} \mathrm{C}\right.$; control, closed circles) and effect of low temperature $\left(4^{\circ} \mathrm{C}\right.$; open circle) on $\left[{ }^{3} \mathrm{H}\right]$ amantadine uptake; ${ }^{* *} p<0.01$, significant difference from the control. (B) Concentration-dependent uptake of amantadine $(1.67 \mu \mathrm{M}-10 \mathrm{mM})$ by RPE-J cells was expressed by using MichaelisMenten and Eadie-Scatchard (inset) plots. Each point in the figure represents the mean $\pm \operatorname{SD}(n=3)$.

\section{A}

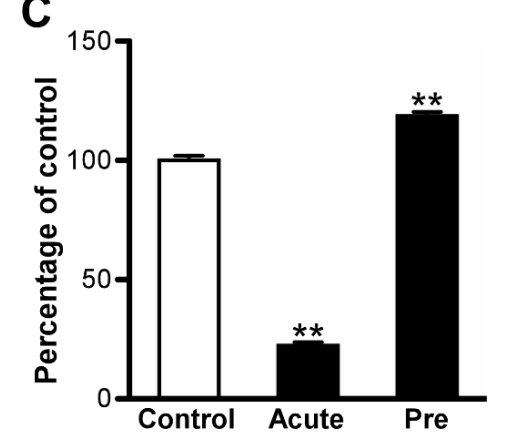

B
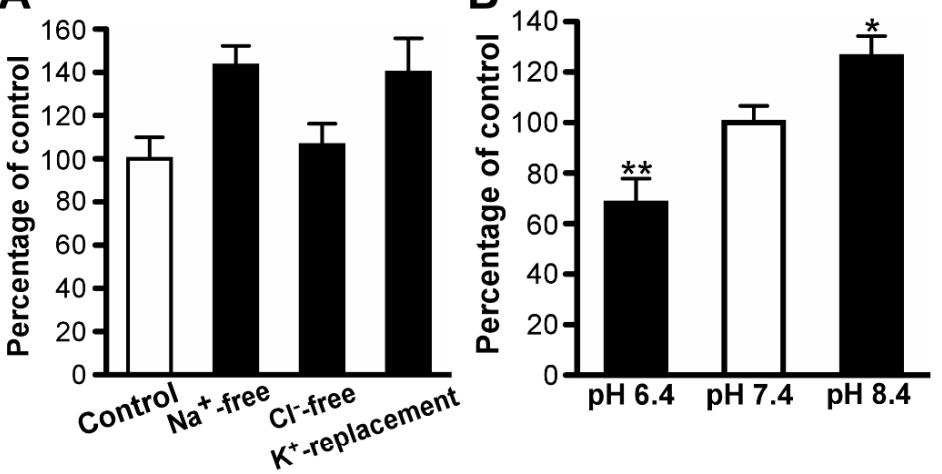

Figure 5. Properties of $\left[{ }^{3} \mathrm{H}\right]$ amantadine uptake by RPE-J cells. (A) Effect of $\mathrm{Na}^{+}, \mathrm{Cl}^{-}$, and membrane potential on $\left[{ }^{3} \mathrm{H}\right]$ amantadine uptake $\left(1.67 \mu \mathrm{M}, 0.1 \mu \mathrm{Ci} /\right.$ well) for $3 \mathrm{~min}$ at $37^{\circ} \mathrm{C}$. (B) Effect of extracellular $\mathrm{pH}$ on the uptake of $\left[{ }^{3} \mathrm{H}\right]$ amantadine. (C) Effect of intracellular $\mathrm{pH}$ on $\left[{ }^{3} \mathrm{H}\right]$ amantadine uptake for $15 \mathrm{~s}$ at $37^{\circ} \mathrm{C}$ by RPE-J cells. Pretreatment (Pre) and acute treatment with $30 \mathrm{mM} \mathrm{NH}_{4} \mathrm{Cl}$ were performed to decrease and increase intracellular $\mathrm{pH}$, respectively. Each column in the figure represents the mean $\pm \operatorname{SD}(n=3) ;{ }^{*} p<0.05,{ }^{* *} p<0.01$, significantly different from the control. 


\subsection{Inhibition of $\left[{ }^{3} \mathrm{H}\right]$ Amantadine Transport by Drugs/Compounds}

The inhibitory effects on the in vitro $\left[{ }^{3} \mathrm{H}\right]$ amantadine uptake are summarized in Table 2 . At $0.2 \mathrm{mM}$, several cationic drugs (desipramine, imipramine, quinidine, and verapamil) strongly inhibited $\left[{ }^{3} \mathrm{H}\right]$ amantadine uptake by both TR-iBRB2 cells and RPE-J cells.

Table 2. Effect of compounds on the uptake of $\left[{ }^{3} \mathrm{H}\right]$ amantadine by TR-iBRB2 cells and RPE-J cells.

\begin{tabular}{|c|c|c|c|}
\hline \multirow[t]{2}{*}{ Compound } & \multirow{2}{*}{$\begin{array}{l}\text { Concentration } \\
(\mathrm{mM})\end{array}$} & \multicolumn{2}{|c|}{$\%$ of Control } \\
\hline & & TR-iBRB2 & RPE-J \\
\hline Control & & $100 \pm 12$ & $100 \pm 12$ \\
\hline Desipramine & 0.2 & $7.05 \pm 0.57^{* *}$ & $10.7 \pm 5.6^{* *}$ \\
\hline Imipramine & 0.2 & $8.37 \pm 1.43^{* *}$ & $16.9 \pm 5.2$ ** \\
\hline Propranolol & 0.2 & $8.61 \pm 0.75^{* *}$ & $15.7 \pm 5.9^{* *}$ \\
\hline Quinidine & 0.2 & $13.7 \pm 1.8^{* *}$ & $34.1 \pm 3.0$ ** \\
\hline \multirow[t]{2}{*}{ Memantine } & 0.2 & $16.7 \pm 2.2^{* *}$ & $123 \pm 38^{* *}$ \\
\hline & 1.0 & N.D. & $27.1 \pm 2.6^{* *}$ \\
\hline \multirow[t]{2}{*}{ Pyrilamine } & 0.2 & $20.9 \pm 1.8^{* *}$ & $77.8 \pm 38.4$ \\
\hline & 1.0 & N.D. & $18.2 \pm 1.7^{* *}$ \\
\hline Verapamil & 0.2 & $22.1 \pm 6.2^{* *}$ & $20.5 \pm 4.8^{* *}$ \\
\hline \multirow[t]{2}{*}{ Amantadine } & 0.2 & $34.1 \pm 4.1^{* *}$ & $89.9 \pm 5.6$ \\
\hline & 1.0 & N.D. & $21.3 \pm 3.1^{* *}$ \\
\hline Timolol & 0.2 & $34.6 \pm 10.6^{* *}$ & $59.1 \pm 5.1$ \\
\hline \multirow[t]{2}{*}{ Clonidine } & 0.2 & $42.1 \pm 12.1^{* *}$ & $71.6 \pm 4.7$ \\
\hline & 1.0 & N.D. & $30.8 \pm 4.0^{* *}$ \\
\hline Pyrimethamine & 0.2 & $44.3 \pm 8.8^{* *}$ & $88.9 \pm 3.3$ \\
\hline PAH & 0.2 & $85.8 \pm 10.8$ & $139 \pm 33$ \\
\hline Acetazolamide & 0.2 & $90.9 \pm 3.8$ & N.D. \\
\hline Gluconate & 0.2 & $91.7 \pm 21.7$ & $86.2 \pm 23.4$ \\
\hline Cimetidine & 0.2 & $97.6 \pm 24.7$ & $106 \pm 5$ \\
\hline Choline & 0.2 & $101 \pm 8$ & $124 \pm 39$ \\
\hline \multirow[t]{2}{*}{$\mathrm{MPP}^{+}$} & 0.2 & $106 \pm 31$ & $75.5 \pm 5.0$ \\
\hline & 1.0 & N.D. & $91.9 \pm 5.6$ \\
\hline \multirow[t]{2}{*}{ Decynium-22 } & 0.2 & $106 \pm 31$ & $86.7 \pm 41.9$ \\
\hline & 0.5 & N.D. & $136 \pm 8$ \\
\hline \multirow[t]{2}{*}{ L-Carnitine } & 0.2 & $111 \pm 35$ & $95.1 \pm 5.2$ \\
\hline & 2.5 & $99.5 \pm 2.3$ & $119 \pm 28$ \\
\hline \multirow[t]{2}{*}{ TEA } & 0.2 & $117 \pm 45$ & $87.7 \pm 11.8$ \\
\hline & 1.0 & N.D. & $81.8 \pm 10.3$ \\
\hline Serotonin & 0.2 & $126 \pm 60$ & $158 \pm 52 * *$ \\
\hline L-Glutamic acid & 2.5 & $80.2 \pm 10.0$ & $84.5 \pm 16.4$ \\
\hline L-Aspartic acid & 2.5 & $101 \pm 23$ & $79.5 \pm 12.7$ \\
\hline Glycine & 2.5 & $102 \pm 4$ & $116 \pm 13$ \\
\hline L-Leucine & 2.5 & $112 \pm 17$ & $113 \pm 16$ \\
\hline L-Arginine & 2.5 & $127 \pm 15$ & $150 \pm 38^{* *}$ \\
\hline
\end{tabular}

Uptake of $\left[{ }^{3} \mathrm{H}\right]$ amantadine $(1.67 \mu \mathrm{M}, 0.1 \mu \mathrm{Ci} /$ well $)$ by the indicated cells was performed for $3 \mathrm{~min}$ at $37^{\circ} \mathrm{C}$. Each value represents the mean $\pm \mathrm{SD}(n=3-30) ;{ }^{* *} p<0.01$, significantly different from the control. $\mathrm{PAH}, p$-aminohippuric acid; $\mathrm{MPP}^{+}, 1-$ methyl-4-phenylpyridinium; TEA, tetraethylammonium; N.D., not determined.

Memantine, pyrilamine, amantadine, and clonidine $(0.2 \mathrm{mM})$ exhibited a marked inhibition of $\left[{ }^{3} \mathrm{H}\right] \mathrm{amantadine}$ uptake by TR-iBRB2 cells but not RPE-J cells; however, these cationic drugs significantly inhibited $\left[{ }^{3} \mathrm{H}\right]$ amantadine uptake by RPE-J cells at $1 \mathrm{mM}$. SLC organic cation/anion transporter substrates, such as $\mathrm{PAH}$, cimetidine, choline, 1-methyl-4-phenylpyridinium $\left(\mathrm{MPP}^{+}\right)$, and decynium-22, did not suppress $\left[{ }^{3} \mathrm{H}\right]$ amantadine uptake. Similarly, anionic and cationic amino acids, including L-glutamic acid and L-arginine, did not significantly impact $\left[{ }^{3} \mathrm{H}\right]$ amantadine uptake.

\subsection{Mutual Effect of Amantadine and Verapamil on Uptake by TR-iBRB2 Cells}

We next examined the involvement of verapamil-sensitive putative transport systems in the inner BRB [20] in amantadine transport. Accordingly, we performed a kinetic analysis of amantadine uptake by TR-iBRB2 cells in the presence of verapamil. On analyzing the Lineweaver-Burk plot, the fitted line of concentration-dependent amantadine uptake by TR-iBRB2 cells in the presence of $10 \mu \mathrm{M}$ verapamil did not intersect with that in the absence of verapamil, on both the $y$-axis and $x$-axis 
(Figure 6A). In the presence of amantadine at $220 \mu \mathrm{M}$, the fitted line of concentration-dependent verapamil uptake intersected at the $y$-axis with that in the absence of amantadine (Figure 6B); this indicated that amantadine competitively inhibits verapamil-sensitive transport mechanisms at the inner BRB.
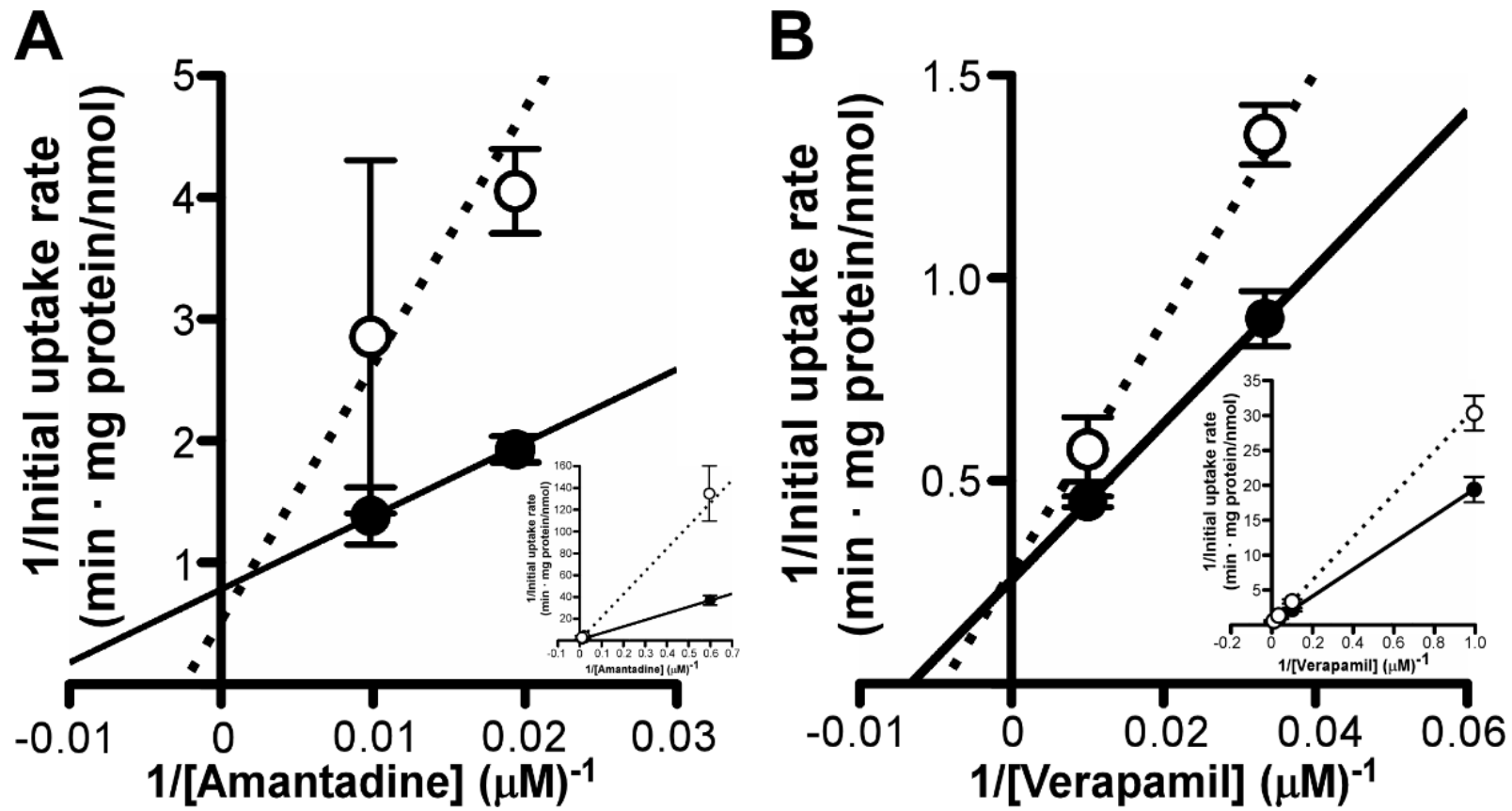

Figure 6. Mutual effect on uptake by TR-iBRB2 cells of amantadine (A) and verapamil (B). (A) The uptake of amantadine at a concentration of $1.67,50,100$, and $300 \mu \mathrm{M}$ was assessed at $37^{\circ} \mathrm{C}$ for $3 \mathrm{~min}$, with (open circles, dotted line) or without (closed circles, solid line) $10 \mu \mathrm{M}$ verapamil. (B) The uptake of verapamil at a concentration of 1, 10, 100, and $300 \mu \mathrm{M}$ was examined at $37^{\circ} \mathrm{C}$ for $3 \mathrm{~min}$, with (open circles, dotted line) or without (closed circles, solid line) $220 \mu \mathrm{M}$ amantadine. Each point in the Lineweaver-Burk plot of all data (inset) and highlighted data at the high concentration range represents the mean $\pm \mathrm{SD}(n=3)$.

\subsection{Effect of Amantadine on Concentration-Dependent Verapamil Uptake by RPE-J Cells}

The effect of amantadine on verapamil-sensitive putative transport systems in the outer BRB was investigated. Herein, we investigated the time-dependent uptake of verapamil by RPE-J cells. RPE-J cells showed a time-dependent increase with an initial uptake rate of $70.4 \pm 5.6 \mu \mathrm{L} /(\mathrm{min} \cdot \mathrm{mg}$ protein) in $\left[{ }^{3} \mathrm{H}\right]$ verapamil uptake for at least $3 \mathrm{~min}$ (Figure $\left.7 \mathrm{~A}\right)$. At $1 \mathrm{~min}$, this $\left[{ }^{3} \mathrm{H}\right]$ verapamil uptake was reduced with $200 \mu \mathrm{M}$ unlabeled verapamil by $86 \%$ (Figure 7A). In RPE-J cells, verapamil uptake exhibited a saturable process, with a $V_{\max }$ value of $6.31 \pm 0.35 \mathrm{nmol} /(\mathrm{min} \cdot \mathrm{mg}$ protein) and a $K_{\mathrm{m}}$ value of $55.6 \pm 5.2 \mu \mathrm{M}$ (Figure 7B). In the Lineweaver-Burk plot analysis, the fitted line of concentration-dependent verapamil uptake by RPE-J cells in the presence of $200 \mu \mathrm{M}$ amantadine did not intersect with that in the absence of verapamil, at both the $y$-axis and $x$-axis (Figure 7B); this suggested that amantadine does not competitively or non-competitively inhibit verapamil transport at the outer BRB. 

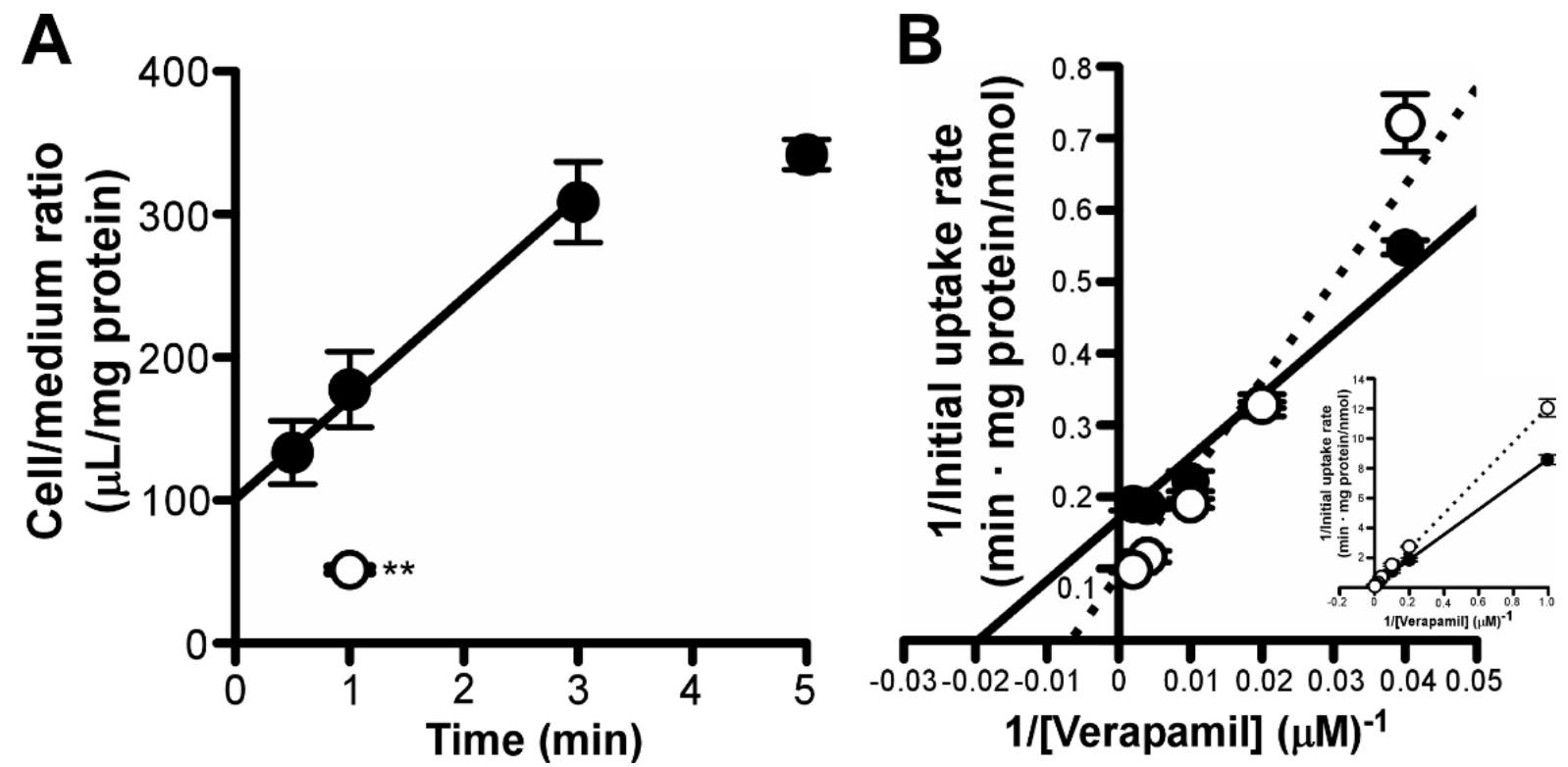

Figure 7. Effects of amantadine on uptake of $\left[{ }^{3} \mathrm{H}\right]$ verapamil by RPE-J cells. (A) Time dependency and self-inhibition of $\left[{ }^{3} \mathrm{H}\right]$ verapamil uptake by RPE-J cells. RPE-J cells were incubated with $\left[{ }^{3} \mathrm{H}\right]$ verapamil $(6.25 \mathrm{nM}, 0.1 \mu \mathrm{Ci} /$ well $)$, in the presence (open circle) or absence (control, closed circles) of $200 \mu \mathrm{M}$ verapamil at $37^{\circ} \mathrm{C}$. (B) Lineweaver-Burk plot of all data (inset) and highlighted data at the concentration of 5, 10, 25, 50, 100, 250, and $500 \mu \mathrm{M}$ verapamil uptake at $37^{\circ} \mathrm{C}$ for $3 \mathrm{~min}$, in the absence (closed circles, solid line) or presence (open circles, dotted line) of $100 \mu \mathrm{M}$ amantadine by RPE-J cells. Each point in the Figure represents the mean $\pm \operatorname{SD}(n=3) ;{ }^{* *} p<0.01$, significant difference from the control.

\section{Discussion}

We assessed the inner and outer BRB-mediated transport of amantadine, as well as the carriermediated transport of amantadine in the inner and outer BRB. Detailed in vitro analyses clarified characteristics of amantadine transport mechanisms at the BRB; however, the involvement of typical organic cation transporters and putative cationic drug transport systems in the carrier-mediated amantadine transport at the BRB is not suggested.

The in vivo retinal drug transfer study (Figure 1) indicated that amantadine underwent active retinal distribution from the circulating blood. Previously, we reported the correlation between in vivo retinal distribution of drugs transported by passive diffusion and lipophilic properties, indicated as $\log \mathrm{D}\{\mathrm{RUI}=46.2 \times \exp (0.515 \times \log \mathrm{D})\}$ [26]. The $\log \mathrm{D}$ value of amantadine is 0.176 [31]. Therefore, if amantadine is only transported to the rat retina by passive diffusion across the in vivo BRB, the RUI value of amantadine can be estimated as $50.4 \%\{=46.2 \times \exp (0.515 \times 0.176)\}$. Compared with this estimated value, the RUI value of $\left[{ }^{3} \mathrm{H}\right]$ amantadine in the present study was 2.5 -fold greater $(129 \%)$. In addition, unlabeled amantadine at $50 \mathrm{mM}$ showed a significant reduction in the $\left[{ }^{3} \mathrm{H}\right]$ amantadine RUI; however, $\mathrm{PAH}$ at the same concentration demonstrated a minimal impact. Based on these findings, it can be suggested that carrier-mediated transport at the inner and outer BRB promotes the retinal distribution of amantadine.

Furthermore, transport studies using in vitro models of the inner and outer BRB detected carriermediated amantadine transport at these barriers. In TR-iBRB2 cells, both saturable and non-saturable components were involved in the uptake of amantadine, with a $K_{\mathrm{m}}$ value of $79.4 \mu \mathrm{M}$ (Figure $2 \mathrm{~B}$ ). As the contribution ratio of the saturable component was $86 \%\left\{=V_{\max } / K_{\mathrm{m}} \div\left(V_{\max } / K_{\mathrm{m}}+K_{\mathrm{d}}\right) \times 100\right\}$, carrier-mediated processes of amantadine uptake could play an important role in amantadine transport at the inner BRB. In terms of the kinetic analysis of amantadine uptake by RPE-J cells, it was observed that this uptake was composed of two saturable processes, with $K_{\mathrm{m}}$ values of 90.5 and $9830 \mu \mathrm{M}$ for high- and low-affinity processes, respectively (Figure 4B). The contributions of high- and low-affinity processes were calculated as $54 \%\left\{=V_{\max 1} / K_{\mathrm{m} 1} \div\left(\mathrm{V}_{\max 1} / K_{\mathrm{m} 1}+V_{\max 2} / K_{\mathrm{m} 2}\right) \times 100\right\}$ and $46 \%\left\{=V_{\max 2} / K_{\mathrm{m} 2} \div\left(V_{\max 1} / K_{\mathrm{m} 1}+V_{\max 2} / K_{\mathrm{m} 2}\right) \times 100\right\}$, respectively; this indicated that the involvement of the high-affinity process in carrier-mediated amantadine transport at the outer BRB is equal to that of the low-affinity process. Collectively, these results suggest that carrier-mediated processes play a major role in amantadine transport across the inner and outer BRB.

As described in the previous section, the $K_{\mathrm{m}}$ value for the saturable process of amantadine uptake by TR-iBRB2 cells $(79.4 \mu \mathrm{M})$ is similar to that determined for the high-affinity process of 
amantadine uptake by RPE-J cells $(90.5 \mu \mathrm{M})$. However, the contribution ratios of saturable kinetics $(50-100 \mu \mathrm{M})$ in TR-iBRB2 and RPE-J cells were $86 \%$ and $54 \%$, respectively. This difference may influence the properties of net amantadine transport at the inner and outer BRB. For example, TRiBRB2 cells exhibited $\mathrm{Cl}^{-}$-sensitive $\left[{ }^{3} \mathrm{H}\right]$ amantadine uptake; this effect was not observed in RPE-J cells (Figures 3A and 5A). Moreover, several cationic compounds, such as memantine, pyrilamine, and clonidine, demonstrated a lower inhibitory effect $(0.2 \mathrm{mM})$ on $\left[{ }^{3} \mathrm{H}\right]$ amantadine uptake by RPE-J cells than that on uptake by TR-iBRB2 cells (Table 2). The characteristics of high- and low-affinity processes need to be individually evaluated to clarify the differences. Nevertheless, our study, including kinetic analyses, implies that the net transport of amantadine at the inner BRB differs from that at the outer BRB.

Although several transporters reportedly accept amantadine as a substrate, our study indicates a minor contribution of these transporters and putative transport systems in terms of amantadine transport at the inner and outer BRB. We observed no inhibitory effect of OCTs and/or $\mathrm{ATB}^{0,+}$ inhibitors, such as decynium-22, TEA, $\mathrm{MPP}^{+}$, glycine, and L-arginine, on $\left[{ }^{3} \mathrm{H}\right]$ amantadine uptake by both model cells (Table 2) [32-38]; this indicates that OCTs and $\mathrm{ATB}^{0,+}$ were not involved in amantadine transport at the inner and outer BRB. In addition, typical organic cation transporters that are expressed in the inner and outer BRB, such as OCTN1-2, MATE1, and PMAT, play a minor role in amantadine transport because substrates of these transporters (cimetidine, L-carnitine, TEA, MPP ${ }^{+}$, and serotonin [39-46]) did not significantly reduce $\left[{ }^{3} \mathrm{H}\right]$ amantadine uptake by these cells (Table 2). Regarding unidentified cationic drug transport systems for clonidine, propranolol, and verapamil at the BRB [20-22], amantadine transport mechanisms at the inner and outer BRB appear distinct from these cationic drug transport systems based on our results. The $K_{\mathrm{m}}$ values for clonidine and propranolol uptake by TR-iBRB2 cells are 286 and $237 \mu \mathrm{M}$, respectively [21,22]. As [ ${ }^{3} \mathrm{H}$ ]amantadine uptake by TR-iBRB2 cells was reduced by more than $58 \%$ in the presence of clonidine and propranolol $(0.2 \mathrm{mM})$, which is lower than the $K_{\mathrm{m}}$ values described above, it is unlikely that putative cationic drug transport systems for clonidine and propranolol participate in amantadine transport at the inner BRB. Reportedly, novel verapamil transport systems have been identified in the rat inner BRB in vitro [20]. In addition, the uptake study of verapamil using RPE-J cells indicated the existence of carrier-mediated verapamil transport in the rat outer BRB (Figure 7), as well as human RPE cells [23]. However, it is strongly suggested that amantadine transport systems at the inner and outer BRB are distinct from the verapamil transport systems considering the mutual effect of amantadine and verapamil on uptake by TR-iBRB2 and RPE-J cells (Figures 6A and 7B). Collectively, the results of the functional study suggest that retinal distribution of amantadine across the inner and outer BRB occurs via carrier-mediated transport systems that do not consist of known organic cation transporters and putative organic cation transport systems for cationic drugs, including verapamil.

Parsons et al. reported that amantadine inhibits NMDA receptors, with an $\mathrm{IC}_{50}$ of $20 \mu \mathrm{M}$ [47]. During pharmacotherapy for Parkinson's disease, the plasma concentration range of $0.6-29 \mu \mathrm{M}$ for amantadine has been established [48]. As the $K_{\mathrm{m}}$ values for the relatively high-affinity process of amantadine transport in the in vitro inner and outer BRB model cells $(50-100 \mu \mathrm{M})$ were greater than the concentrations related to the pharmacology and pharmaceutics of amantadine, carrier-mediated amantadine transport at the inner/outer BRB is critical for understanding retinal amantadine distribution. Hence, identifying amantadine transport systems at the BRB could help establish an appropriate pharmaceutical strategy for amantadine applications in retinal diseases. For the identification of the molecule involved in the relatively high-affinity process of amantadine uptake, TR-iBRB2 cells may afford an advantage, as the relatively high-affinity process was the only observed carrier-mediated process of amantadine transport.

\section{Conclusions}

In the current study, we demonstrated the process of retinal amantadine transport. The RUI experiment indicated the retinal distribution of amantadine. Moreover, the uptake study using in vitro model cells suggested the involvement of transport systems in amantadine blood-to-retina transport across the inner and outer BRB. Furthermore, it can be suggested that transport systems for amantadine at the inner/outer BRB are independent of cationic drug transport systems for verapamil, as well as SLC organic cation and amino acid transporters. These transport systems for amantadine at the BRB promote amantadine distribution to the retina. Therefore, the characteristics of amantadine transport at the BRB identified in this study can provide an in-depth understanding of amantadine-sensitive transport mechanisms at the BRB and, thus, the utilization of adamantane derivatives, such as amantadine, for retinal diseases. 
Supplementary Materials: The Supplemental Materials are available online at https:/ www.mdpi. com/article/10.3390/pharmaceutics13091339/s1. Figure S1. The cellular protein amount in the group of Figure 3. Each column represents the mean \pm S.D. $(n=3)$. In the tested group, the significant difference from the control was not observed $(p>0.05)$. Figure S2. The cellular protein amount in the group of Figure 5. Each column represents the mean \pm S.D. $(n=3)$. In the tested group, the significant difference from the control was not observed $(p>0.05)$.

Author Contributions: Conception, Y.S., S.-i.A., Y.K. and K.-i.H.; collection, assembly of data, and interpretation, Y.S., S.-i.A. and Y.M.; writing the manuscript, Y.S., S.-i.A. and K.-i.H. All authors have read and agreed to the published version of the manuscript.

Funding: This study was supported by Grant-in-Aids from the Japan Society for Promotion of Science, KAKENHI (Scientific Research (B), 16H05110 and 20H03403; Scientific Research (C), 19K07160).

Institutional Review Board Statement: The animal study was conducted according to the guidelines of the Animal Care Committee of the University of Toyama and approved by the Committee (A2017PHA-6 (date of approval: 14 March 2017) and A2020PHA-1 (date of approval: 9 March 2020)).

Informed Consent Statement: Not applicable.

Data Availability Statement: The data of this study are available from the corresponding author upon reasonable request.

Conflicts of Interest: The authors declare no conflict of interest.

\section{References}

1. McMonnies, C.W. Glaucoma history and risk factors. J. Optom. 2017, 10, 71-78. [CrossRef]

2. Lechner, J.; O'Leary, O.E.; Stitt, A.W. The pathology associated with diabetic retinopathy. Vis. Res. 2017, 139, 7-14. [CrossRef]

3. Fechtner, R.D.; Weinreb, R.N. Mechanisms of optic nerve damage in primary open angle glaucoma. Surv. Ophthalmol. 1994, 39, 23-42. [CrossRef]

4. Lipton, S.A. Possible role for memantine in protecting retinal ganglion cells from glaucomatous damage. Surv. Ophthalmol. 2003, 48, S38-S46. [CrossRef]

5. Luo, X.; Heidinger, V.; Picaud, S.; Lambrou, G.; Dreyfus, H.; Sahel, J.; Hicks, D. Selective excitotoxic degeneration of adult pig retinal ganglion cells in vitro. Invest. Ophthalmol. Vis. Sci. 2001, 42, 1096-1106.

6. Chidlow, G.; Osborne, N.N. Rat retinal ganglion cell loss caused by kainate, NMDA and ischemia correlates with a reduction in mRNA and protein of Thy-1 and neurofilament light. Brain Res. 2003, 963, 298-306. [CrossRef]

7. Hare, W.A.; Wheeler, L. Experimental glutamatergic excitotoxicity in rabbit retinal ganglion cells: Block by memantine. Invest. Ophthalmol. Vis. Sci. 2009, 50, 2940-2948. [CrossRef]

8. Hare, W.; WoldeMussie, E.; Lai, R.; Ton, H.; Ruiz, G.; Feldmann, B.; Wijono, M.; Chun, T.; Wheeler, L. Efficacy and safety of memantine, an NMDA-type open-channel blocker, for reduction of retinal injury associated with experimental glaucoma in rat and monkey. Surv. Ophthalmol. 2001, 45, S284-S289. [CrossRef]

9. Weinreb, R.N.; Liebmann, J.M.; Cioffi, G.A.; Goldberg, I.; Brandt, J.D.; Johnson, C.A.; Zangwill, L.M.; Schneider, S.; Badger, H.; Bejanian, M. Oral memantine for the treatment of glaucoma: Design and results of 2 randomized, placebo-controlled, phase 3 studies. Ophthalmology 2018, 125, 1874-1885. [CrossRef]

10. Bucolo, C.; Platania, C.B.M.; Drago, F.; Bonfiglio, V.; Reibaldi, M.; Avitabile, T.; Uva, M. Novel therapeutics in glaucoma management. Curr. Neuropharmacol. 2018, 16, 978-992. [CrossRef]

11. Cunha-Vaz, J.G. The blood-retinal barriers system. Basic concepts and clinical evaluation. Exp. Eye. Res. 2004, 78, 715-721. [CrossRef]

12. Liu, L.; Liu, X. Roles of drug transporters in blood-retinal barrier. Adv. Exp. Med. Biol. 2019, 1141, 467-504. [PubMed]

13. Aoki, F.Y.; Sitar, D.S.; Ogilvie, R.I. Amantadine kinetics in healthy young subjects after long-term dosing. Clin. Pharmacol. Ther. 1979, 26, 729-736. [CrossRef] [PubMed]

14. Muller, F.; Weitz, D.; Derdau, V.; Sandvoss, M.; Mertsch, K.; Konig, J.; Fromm, M.F. Contribution of MATE1 to renal secretion of the NMDA receptor antagonist memantine. Mol. Pharm. 2017, 14, 2991-2998. [CrossRef] [PubMed]

15. Kooijmans, S.A.; Senyschyn, D.; Mezhiselvam, M.M.; Morizzi, J.; Charman, S.A.; Weksler, B.; Romero, I.A.; Couraud, P.O.; Nicolazzo, J.A. The involvement of a $\mathrm{Na}(+)$ - and $\mathrm{Cl}(-)$-dependent transporter in the brain uptake of amantadine and rimantadine. Mol. Pharm. 2012, 9, 883-893. [CrossRef] [PubMed]

16. Goralski, K.B.; Lou, G.; Prowse, M.T.; Gorboulev, V.; Volk, C.; Koepsell, H.; Sitar, D.S. The cation transporters rOCT1 and rOCT2 interact with bicarbonate but play only a minor role for amantadine uptake into rat renal proximal tubules. J. Pharmacol. Exp. Ther. 2002, 303, 959-968. [CrossRef]

17. Busch, A.E.; Karbach, U.; Miska, D.; Gorboulev, V.; Akhoundova, A.; Volk, C.; Arndt, P.; Ulzheimer, J.C.; Sonders, M.S.; Baumann, C.; et al. Human neurons express the polyspecific cation transporter hOCT2, which translocates monoamine neurotransmitters, amantadine, and memantine. Mol. Pharmacol. 1998, 54, 342-352. [CrossRef] 
18. Tachikawa, M.; Takeda, Y.; Tomi, M.; Hosoya, K. Involvement of OCTN2 in the transport of acetyl-L-carnitine across the inner blood-retinal barrier. Invest. Ophthalmol. Vis. Sci. 2010, 51, 430-436. [CrossRef]

19. Kubo, Y.; Yamamoto, M.; Matsunaga, K.; Usui, T.; Akanuma, S.I.; Hosoya, K.I. Retina-to-blood transport of 1-methyl-4phenylpyridinium involves carrier-mediated process at the blood-retinal barrier. J. Pharm. Sci. 2017, 106, 2583-2591. [CrossRef]

20. Kubo, Y.; Kusagawa, Y.; Tachikawa, M.; Akanuma, S.; Hosoya, K. Involvement of a novel organic cation transporter in verapamil transport across the inner blood-retinal barrier. Pharm. Res. 2013, 30, 847-856. [CrossRef]

21. Kubo, Y.; Shimizu, Y.; Kusagawa, Y.; Akanuma, S.; Hosoya, K. Propranolol transport across the inner blood-retinal barrier: Potential involvement of a novel organic cation transporter. J. Pharm. Sci. 2013, 102, 3332-3342. [CrossRef] [PubMed]

22. Kubo, Y.; Tsuchiyama, A.; Shimizu, Y.; Akanuma, S.; Hosoya, K. Involvement of carrier-mediated transport in the retinal uptake of clonidine at the inner blood-retinal barrier. Mol. Pharm. 2014, 11, 3747-3753. [CrossRef] [PubMed]

23. Han, Y.H.; Sweet, D.H.; Hu, D.N.; Pritchard, J.B. Characterization of a novel cationic drug transporter in human retinal pigment epithelial cells. J. Pharmacol. Exp. Ther. 2001, 296, 450-457.

24. Hosoya, K.; Tomi, M.; Ohtsuki, S.; Takanaga, H.; Ueda, M.; Yanai, N.; Obinata, M.; Terasaki, T. Conditionally immortalized retinal capillary endothelial cell lines (TR-iBRB) expressing differentiated endothelial cell functions derived from a transgenic rat. Exp. Eye. Res. 2001, 72, 163-172. [CrossRef] [PubMed]

25. Nabi, I.R.; Mathews, A.P.; Cohen-Gould, L.; Gundersen, D.; Rodriguez-Boulan, E. Immortalization of polarized rat retinal pigment epithelium. J. Cell. Sci. 1993, 104, 37-49. [CrossRef]

26. Hosoya, K.; Yamamoto, A.; Akanuma, S.; Tachikawa, M. Lipophilicity and transporter influence on blood-retinal barrier permeability: A comparison with blood-brain barrier permeability. Pharm. Res. 2010, 27, 2715-2724. [CrossRef]

27. Kubo, Y.; Yamada, M.; Konakawa, S.; Akanuma, S.I.; Hosoya, K.I. Uptake study in lysosome-enriched fraction: Critical involvement of lysosomal trapping in quinacrine uptake but not fluorescence-labeled verapamil transport at blood-retinal barrier. Pharmaceutics 2020, 12, 747. [CrossRef] [PubMed]

28. Tega, Y.; Tabata, H.; Kurosawa, T.; Kitamura, A.; Itagaki, F.; Oshitari, T.; Deguchi, Y. Structural requirements for uptake of diphenhydramine analogs into hCMEC/D3 cells via the proton-coupled organic cation antiporter. J. Pharm. Sci. 2021, 110,397-403. [CrossRef]

29. Lin, H.; Miller, S.S. pHi regulation in frog retinal pigment epithelium: Two apical membrane mechanisms. Am. J. Physiol. 1991, 261, C132-C142. [CrossRef]

30. Yamaoka, K.; Tanigawara, Y.; Nakagawa, T.; Uno, T. A pharmacokinetic analysis program (multi) for microcomputer. J. Pharmacobiodyn. 1981, 4, 879-885. [CrossRef]

31. Grabowski, T.; Gumulka, S.W.; Borucka, B.; Raszewski, W. Analysis relationships between pharmacokinetic parameters in silico/in vivo of selected antiviral drugs based on structural analysis. Adv. Clin. Exp. Med. 2008, 17, $285-292$.

32. Grundemann, D.; Gorboulev, V.; Gambaryan, S.; Veyhl, M.; Koepsell, H. Drug excretion mediated by a new prototype of polyspecific transporter. Nature 1994, 372, 549-552. [CrossRef]

33. Urakami, Y.; Okuda, M.; Masuda, S.; Saito, H.; Inui, K.I. Functional characteristics and membrane localization of rat multispecific organic cation transporters, OCT1 and OCT2, mediating tubular secretion of cationic drugs. J. Pharmacol. Exp. Ther. 1998, 287, 800-805. [PubMed]

34. Grundemann, D.; Babin-Ebell, J.; Martel, F.; Ording, N.; Schmidt, A.; Schomig, E. Primary structure and functional expression of the apical organic cation transporter from kidney epithelial LLC-PK1 cells. J. Biol. Chem. 1997, 272, 10408-10413. [CrossRef] [PubMed]

35. Kekuda, R.; Prasad, P.D.; Wu, X.; Wang, H.; Fei, Y.J.; Leibach, F.H.; Ganapathy, V. Cloning and functional characterization of a potential-sensitive, polyspecific organic cation transporter (OCT3) most abundantly expressed in placenta. J. Biol. Chem. 1998, 273, 15971-15979. [CrossRef] [PubMed]

36. Wu, X.; Kekuda, R.; Huang, W.; Fei, Y.J.; Leibach, F.H.; Chen, J.; Conway, S.J.; Ganapathy, V. Identity of the organic cation transporter OCT3 as the extraneuronal monoamine transporter (uptake2) and evidence for the expression of the transporter in the brain. J. Biol. Chem. 1998, 273, 32776-32786. [CrossRef]

37. Sloan, J.L.; Mager, S. Cloning and functional expression of a human $\mathrm{Na}(+)$ and $\mathrm{Cl}(-)$-dependent neutral and cationic amino acid transporter B(0+). J. Biol. Chem. 1999, 274, 23740-23745. [CrossRef] [PubMed]

38. Nakanishi, T.; Hatanaka, T.; Huang, W.; Prasad, P.D.; Leibach, F.H.; Ganapathy, M.E.; Ganapathy, V. Na+- and Cl-coupled active transport of carnitine by the amino acid transporter ATB $(0,+)$ from mouse colon expressed in HRPE cells and Xenopus oocytes. $J$. Physiol. 2001, 532, 297-304. [CrossRef]

39. Yabuuchi, H.; Tamai, I.; Nezu, J.; Sakamoto, K.; Oku, A.; Shimane, M.; Sai, Y.; Tsuji, A. Novel membrane transporter OCTN1 mediates multispecific, bidirectional, and pH-dependent transport of organic cations. J. Pharmacol. Exp. Ther. 1999, 289, 768-773.

40. Wu, X.; George, R.L.; Huang, W.; Wang, H.; Conway, S.J.; Leibach, F.H.; Ganapathy, V. Structural and functional characteristics and tissue distribution pattern of rat OCTN1, an organic cation transporter, cloned from placenta. Biochim. Biophys. Acta. 2000, 1466, 315-327. [CrossRef]

41. Wu, X.; Huang, W.; Prasad, P.D.; Seth, P.; Rajan, D.P.; Leibach, F.H.; Chen, J.; Conway, S.J.; Ganapathy, V. Functional characteristics and tissue distribution pattern of organic cation transporter 2 (OCTN2), an organic cation/carnitine transporter. J. Pharmacol. Exp. Ther. 1999, 290, 1482-1492. [PubMed] 
42. Tamai, I.; Ohashi, R.; Nezu, J.; Yabuuchi, H.; Oku, A.; Shimane, M.; Sai, Y.; Tsuji, A. Molecular and functional identification of sodium ion-dependent, high affinity human carnitine transporter OCTN2. J. Biol. Chem. 1998, 273, 20378-20382. [CrossRef] [PubMed]

43. Otsuka, M.; Matsumoto, T.; Morimoto, R.; Arioka, S.; Omote, H.; Moriyama, Y. A human transporter protein that mediates the final excretion step for toxic organic cations. Proc. Natl. Acad. Sci. USA 2005, 102, 17923-17928. [CrossRef] [PubMed]

44. Ohta, K.Y.; Inoue, K.; Hayashi, Y.; Yuasa, H. Molecular identification and functional characterization of rat multidrug and toxin extrusion type transporter 1 as an organic cation/H+ antiporter in the kidney. Drug. Metab. Dispos. 2006, 34, 1868-1874. [CrossRef] [PubMed]

45. Ito, S.; Kusuhara, H.; Yokochi, M.; Toyoshima, J.; Inoue, K.; Yuasa, H.; Sugiyama, Y. Competitive inhibition of the luminal efflux by multidrug and toxin extrusions, but not basolateral uptake by organic cation transporter 2, is the likely mechanism underlying the pharmacokinetic drug-drug interactions caused by cimetidine in the kidney. J. Pharmacol. Exp. Ther. 2012, 340, 393-403. [CrossRef]

46. Engel, K.; Wang, J. Interaction of organic cations with a newly identified plasma membrane monoamine transporter. Mol. Pharmacol. 2005, 68, 1397-1407. [CrossRef]

47. Parsons, C.G.; Panchenko, V.A.; Pinchenko, V.O.; Tsyndrenko, A.Y.; Krishtal, O.A. Comparative patch-clamp studies with freshly dissociated rat hippocampal and striatal neurons on the NMDA receptor antagonistic effects of amantadine and memantine. Eur. J. Neurosci. 1996, 8, 446-454. [CrossRef]

48. Nishikawa, N.; Nagai, M.; Moritoyo, T.; Yabe, H.; Nomoto, M. Plasma amantadine concentrations in patients with Parkinson's disease. Parkinsonism. Relat. Disord. 2009, 15, 351-353. [CrossRef] 